\title{
Pengaruh Gaya Kepemimpinan Dan Budaya Organisasi Terhadap Kinerja Karyawan PT. PLN (Persero) Wilayah Papua Dan Papua Barat Area Manokwari
}

\author{
Marzellina E. Rumbekwan ${ }^{1}$, Yulius H. Saptomo ${ }^{2}$, Margareth S.Sabarofek ${ }^{2}$ \\ ${ }^{1}$ Alumni Program Studi Manajemen, Universitas Papua \\ ${ }^{2}$ Program Studi Manajemen, Universitas Papua
}

Received: Desember 2018; Accepted: Januari 2019; Published: Maret 2019

\begin{abstract}
Abstrak
Tujuan penelitian ini adalah untuk mengetahui pengaruh gaya kepemimpinan dan budaya organisasi terhadap kinerja karyawan PT PLN (Persero) Wilayah Papua dan Papua Barat Area Manokwari. Penelitian ini merupakan penelitian asosiatif dengan menggunakan data kuantitatif. Sumber data meliputi data primer dan data sekunder. Populasi dalam penelitian adalah ini seluruh karyawan PT PLN (Persero) Wilayah Papua dan Papua Barat Area Manokwari. Metode pengambilan sampel menggunakan simple random sampling dengan jumlah responden 67 karyawan. Data dianalisis menggunakan regresi linear sederhana. Hasil penelitian menunjukkan bahwa, baik secara parsial (uji t) maupun secara simultan (uji F), gaya kepemimpinan dan budaya organisasi berpengaruh signifikan terhadap kinerja karyawan. Nilai Adjusted $R$ Square sebesar 0,495 menunjukkan bahwa 49,5\% variasi kinerja karyawan PT PLN (Persero) Wilayah Papua dan Papua Barat Area Manokwari dipengaruhi oleh gaya kepemimpinan dan budaya organisasi.
\end{abstract}

Kata kunci: gaya kepemimpinan, budaya organisasi, kinerja karyawan

\begin{abstract}
The purpose of this study was to determine the effect of leadership style and organizational culture on the performance of employees of PT PLN (Persero) Region of Papua and West Papua Manokwari Area. This research is an associative study using quantitative data. Data sources include primary data and secondary data. The population in this study were all employees of PT PLN (Persero) in the Papua and West Papua Areas of the Manokwari Area. The sampling method uses simple random sampling with the number of respondents 67 employees. Data were analyzed using simple linear regression. The results showed that, both partially $(t$ test) and simultaneously ( $F$ test), leadership style and organizational culture had a significant effect on employee performance. Adjusted $R$ Square value of 0.495 shows that $49.5 \%$ of the variation in the performance of employees of PT PLN (Persero) in the Papua and West Papua Areas of Manokwari is influenced by leadership style and organizational culture.
\end{abstract}

Keywords: leadership style, organizational culture, employee performance

How to Cite: Rumbekwan, M. E., Saptomo, Y. H., Sabarofek, M. S. (2019). Pengaruh Gaya Kepemimpinan Dan Budaya Organisasi Terhadap Kinerja Karyawan PT. PLN (Persero) Wilayah Papua Dan Papua Barat Area Manokwari. JFRES: Journal of Fiscal and Regional Economy Studies, 2 (1), 93 100. 


\section{PENDAHULUAN}

Sumber daya manusia dalam organisasi memiliki peran yang sangat penting. Organisasi dinyatakan baik jika memiliki kualitas sumber daya manusia yang baik. Menciptakan sumber daya manusia yang kreatif dan inovatif dalam suatu organisasi tidak terlepas dari peran para pemimpin organisasi tersebut. Para pemimpin organisasi itu yang berperan untuk bagaimana menciptakan sumber daya manusia yang mampu untuk berkreatif dan inovatif. Menurut Scheein dalam Muchlas (2005), secara komprehensif budaya organisasi didefinisikan sebagai sebuah corak dari asumsi-asumsi dasar, yang ditemukan atau dikembangkan oleh sebuah kelompok tertentu untuk belajar mengatasi masalahmasalah kelompok dari adaptasi eksternal dan integrase internal, yang telah bekerja dengan baik. Hal itu cukup relevan untuk dipertimbangkan sebagai sesuatu yang bernilai dan, oleh karenanya, pantas diajarkan kepada para anggota baru sebagai cara yang benar untuk berpersepsi, berpikir dan berperasaan dalam hubungannya dengan masalah-masalah tersebut. Menurut Nurjanah dalam Rifai dan Sadarusman (2014), gaya kepemimpian (leadership style) merupakan cara pimpinan untuk mempengaruhi orang lain atau bawahannya sehingga orang tersebut mau melakukan kehendak pemimpin untuk mencapai tujuan organisasi. Sedangkan menurut Tampubolon dalam Rifai dan Sadarusman (2014), gaya kepemimpinan adalah perilaku dan strategi sebagai hasil kombinasi dari falsafah, keterampilan, sifat, dan sikap yang diterapkan oleh seorang pemimpin ketika ia mencoba mempengaruhi kinerja bawahannya. Menurut Patric (2007), secara garis besar ada empat gaya kepemimpinan yang dapat dikenali, yaitu :

1. Kepemimpinan dengan gaya otokrat

Gaya kepemimpinan dengan memerintahkan digunakan ketika pemimpin memberitahukan para pekerjanya akan apa yang dia inginkan dan bagaimana hal itu dilakukan, tanpa harus meminta nasehat terlebih dahulu dari para bawahannya. Gaya kepemimpinan ini bukan berarti berteriak untuk menyerukan, menggunakan bahasa yang kasar, memimpin dengan tangan besi, memberikan gaya memerintah atau gaya ultimatum dan menyalahgunakan otokrat atau melampaui kekuasaan yang telah diberikan. Itulah penyimpangan, gaya kepemimpinan yang tidak professional.
2. Kepemimpinan yang menjual

Gaya kepemimpinan ini adalah gaya ketika pemimpin menggunakan kombinasi antara metode keras dan lembut. Pemimpin ingin segala sesuatu terlaksana dengan baik. Pemimpin berkemauan keras dalam mencapai tujuan atau hasil yang diinginkan tetapi pemimpin mungkin meninggalkan karyawannya untuk memilih pelayanan mereka agar pekerjaan dapat terlaksana dengan baik. Gaya kepemimpinan ini sebagian besar bisa berguna khususnya jika memiliki karyawan yang memenuhi kualifikasi dibidangnya. Biasanya pada gaya kepemimpinan semacam ini, selalu dibutuhkan diskusi-diskusi dan komunikasi yang efektif secara konstan dengan karyawan.

3. Kepemimpinan yang berpatisipasi (gaya QC) Gaya kepemimpinan ini mengharuskan pemimpin untuk melibatkan para karyawan dalam apa yang harus dilakukan oleh suatu perusahaan. Bagaimanapun, pemimpin merupakan orang terakhir yang berkuasa dalam menentukan keputusan. Hal ini tidak menunjukkan kelemahan-kelemahan, tetapi menunjukkan kekuatan bahwa para pegawai menghormati pemimpin.

4. Kepemimpinan yang bersifat delegasi atau kepemimpinan yang memperkuat kedudukan Gaya kepemimpinan semacam ini meletakkan pemimpin pada posisi yang lebih baik untuk membiarkan para pekerja mereka untuk membuat keputusan. Tetapi, sebagai seorang pemimpin, harus tetap bertanggung jawab terhadap keputusan yang telah dibuat. Gaya kepemimpinan ini sangat berguna ketika para pekerja mampu untuk menganalisa situasi dan menentukan apa yang harus dilakukan dan bagaimana cara untuk melakukan hal itu. Pemimpin tidak dapat melakukan segalanya. Pemimpin harus membuat prioritas dan mendelegasikan beberapa tugas.

Konsep budaya organisasi bisa dikatakan masih relatif baru yakni baru berkembang sekitar awal 1980-an. Konsep ini, seperti diakui para teoritis organisasi, diadopsi dari konsep budaya yang terlebih dahulu berkembang pada disiplin antropologi. Oleh karenanya, keragaman pengertian budaya pada disiplin antropologi juga akan berpengaruh terhadap keragaman pengertian pada disiplin organisasi (Sobirin, 2007). Menurut Tosi, dkk dalam Munandar (2008), budaya organisasi adalah "the patterned 
way of thinking, feeling, and reacting that exist in an organization or its subsectors. Is the unique "mental programming" of that organization, which is a reflection of it's modal organization personality" (budaya organisasi adalah cara-cara berpikir, berperasaan, dan bereaksi berdasarkan pola-pola tertentu yang ada dalam organisasi atau yang ada pada bagianbagian organisasi. Menurut Robbins dalam Munandar (2008), menyatakan bahwa hasilhasil penelitian muktahir menemukan bahwa ada 7 (tujuh) ciri-ciri utama yang, secara keseluruhan mencakup esensi dari budaya organisasi. Ketujuh ciri tersebut adalah :

1. Inovasi dan pengambilan risiko. Sejauh mana karyawan didukung untuk menjadi inovatif dan berani mengambil risiko.

2. Perhatian terhadap detail. Sejauh mana karyawan diharapkan menunjukkan kecermatan, analisis dan perhatian terhadap detail.

3. Orientasi ke keluaran. Sejauh mana manajemen lebih berfokus pada hasil-hasil dan keluaran daripada kepada teknik-teknik dan proses yang digunakan untuk mencapai keluaran tersebut.

4. Orientasi ke orang. Sejauh mana keputusankeputusan yang diambil manajemen ikut memperhitungkan dampak dari keluarannya terhadap para karyawannya.

5. Orientasi tim. Sejauh mana kegiatan-kegiatan kerja lebih diorganisasi seputar kelompokkelompok (teams) dari pada seputar perorangan.

6. Keagresifan. Sejauh mana orang-orang lebih agresif dan kompetitif dari pada santai.

7. Stabilitas. Sejauh mana kegiatan-kegiatan keorganisasian lebih menekankan status quo dibandingkan dengan pertumbuhan.

Menurut Bangun (2011), standar pekerjaan dapat ditentukan dari isi suatu pekerjaan, dapat sebagai dasar penilaian setiap pekerjaan. Untuk mempermudah penilaian karyawan, standar pekerjaan harus dapat diukur dan dipahami secara jelas, yaitu :

1. Jumlah pekerjaan

Dimensi ini menunjukkan pekerjaan yang akan dihasilkan individu atau kelompok sebagai persyaratan yang menjadi standar pekerjaan. Setiap pekerjaan memiliki persyaratan yang berbeda sehingga menuntut karyawan harus memenuhi persyaratan tersebut baik pengetahuan, keterampilan, maupun kemampuan yang sesuai. Berdasarkan persyaratan karyawan tersebut dapat diketahui jumlah karyawan yang dapat mengerjakannya, atau setiap karyawan yang dapat mengerjakan beberapa unit pekerjaan.

2. Kualitas pekerjan

Setiap keryawan dalam perusahaan harus memenuhi persyaratan tertentu untuk dapat menghasilkan pekerjaan sesuai kualitas yang dituntut suatu pekerjaan tertentu. Setiap pekerjaan mempunyai standar kualitas tertentu yang harus disesuaikan oleh karyawan untuk dapat mengerjakannya sesuai ketentuan. Karyawan memiliki kinerja baik bila dapat menghasilkan pekerjaan sesuai dengan persyaratan kualitas yang dituntut pekerjaan tersebut.

3. Ketepatan waktu

Setiap pekerjaan memiliki karateristik yang berbeda, untuk jenis pekerjaan tertentu harus diselesaikan tepat waktu, karena memiliki ketergantungan atas pekerjaan lainnya. Jadi bila pekerjaan pada suatu bagian tertentu tidak diselesaikan sesuai tepat waktu akan menghambat pekerjaan pada bagian lain, sehingga mempengaruhi jumlah dan kualitas hasil pekerjaan.

4. Kehadiran

Suatu jenis pekerjaan tertentu menuntut kehadiran karyawan dalam mengerjakannya sesuai waktu yang ditentukan. Ada tipe pekerjaan yang menuntut kehadiran karyawan selama delapan jam sehari. Kinerja karyawan ditentukan oleh tingkat kehadiran karyawan dalam mengerjakannya.

5. Kemampuan kerja sama

Tidak semua pekerjaan dapat diselesaikan oleh satu karyawan saja. Untuk jenis pekerjaan tertentu mungkin harus diselesaikan oleh dua orang karyawan atau lebih, sehingga membutuhkan kerjasama antar karyawan sangat dibutuhkan. Kinerja karyawan dapat dinilai dari kemampuannya bekerja sama dengan rekan sekerja lainnya.

Menurut Hariandja (2002), penilaian kinerja merupakan suatu proses organisasi dalam menilai kinerja pegawainya. Penilaian kinerja tidak hanya menilai, yaitu mencari pada aspek apa pegawai kurang atau lebih, tetapi lebih luas lagi, yaitu membantu pegawai untuk mencapai kinerja yang diharapkan oleh organisasi dan berorientasi kepada pengembangan pegawai atau organisasi. Menurut Bagia (2015), penilaian kinerja merupakan suatu proses penilaian yang dilakukan secara sistematik terhadap kinerja karyawan berdasarkan pekerjaan yang ditugaskan dan dibebankan kepada mereka. 
Penilaian kinerja adalah proses yang dilakukan organisasi untuk mengevaluasi atau menilai keberhasilan karyawan dalam melaksanakan pekerjaannya. Penilaian dapat dilakukan dengan membandingkan hasil kerja yang dicapai karyawan dengan standar pekerjaan (Bangun, 2011).

Melalui survei awal di PT PLN (Persero) Area Manokwari, saat ini, sering terjadi pergantian pemimpin dan pergantian karyawan yang diadakan setiap dua tahun atau empat tahun sekali dan adanya pemutusan hubungan kontrak kerja yang dapat dilakukan lebih dari setahun atau kurang dari setahun (masa percobaan 3 bulan) apabila para pegawainya tidak memenuhi standar kinerja yang ditetapkan dalam PT PLN (Persero) Area Manokwari. Oleh karenanya karyawan PT PLN (Persero) Area Manokwari selalu merasakan adanya perbedaan gaya kepemimpinan karena sering mengalami pergantian pemimpin. Tetapi, meskipun begitu budaya organisai yang sudah ada pada PT PLN (Persero) Area Manokwari tidak mengalami perubahan yang signifikan dari terjadinya pergantian pemimpin karena pada dasarnya budaya organisasi yang ada mengacu pada budaya organisasi yang bersifat internasional. Untuk itu sekalipun berganti pemimpin, budaya organisasi tidak terlalu mengalami perubahan. Berdasarkan hal tersebut, maka yang hendak diteliti dalam penelitian ini adalah apakah terdapat Pengaruh Gaya Kepemimpinan Dan Budaya Organisasi Terhadap Kinerja Pegawai pada PT PLN (Persero) Area Manokwari ?

\section{METODE PENELITIAN}

\section{Populasi dan Sampel}

Populasi pada penelitian ini adalah seluruh wilayah generalisasi PT PLN (Persero) Area Manokwari yakni seluruh pegawai yang berjumlah sebanyak 81 orang. Besarnya jumlah sampel diperoleh dengan menggunakan rumus Slovin, sebagai berikut :

Keterangan :

$$
\frac{N}{1+N e 2}
$$

$\mathrm{N}=$ ukuran populasi

$\mathrm{n}=$ ukuran sampel

$\mathrm{e}=$ tingkat kesalasan toleransi $5 \%(0,05)$

Jadi, jumlah sampel yang digunakan dalam penelitian ini adalah sebanyak 67 sampel.

\section{Skala Pengukuran}

Skala pengukuran dalam penelitian ini adalah dengan menggunakan Skala Likert. Skala likert digunakan untuk mengukur sikap, pendapat dan persepsi seseorang atau sekelompok orang tentang fenomena sosial. Jawaban setiap item instrument yang menggunakan skala likert mempunyai kategori penilaian sebagai berikut (Sugiyono, 2016) :

$\begin{array}{ll}\text { 1. Sangat Setuju Diberi Skor } & : 5 \\ \text { 2. Setuju Diberi Skor } & : 4 \\ \text { 3. Ragu - Ragu Diberi Skor } & : 3 \\ \text { 4. Tidak Setuju Diberi Skor } & : 2 \\ \text { 5. Sangat Tidak Setuju Diberi Skor } & : 1\end{array}$

\section{Metode Analisis Data}

Analisis data yang digunakan peneliti dalam penelitian ini adalah analisis regresi linear beganda. Regresi linear berganda digunakan untuk mengukur kekuatan hubungan antara variabel atau lebih juga menunjukkan arah hubungan antara variabel dependen dengan variabel independen ). Persamaan regresi linear berganda yang digunakan adalah sebagai berikut:

$$
\mathbf{Y}=\alpha+\beta_{1} X_{1}+\beta_{2} X_{2}+e
$$

dimana :

$\alpha$ : intersep

$\beta_{i}:$ koefisien regresi

$X_{i}$ : variabel independen

$Y_{i} \quad$ : variabel dependen

$e$ : error term

\section{HASIL DAN PEMBAHASAN}

\section{Uji Statistik Secara Pasrsial (Uji t)}

Hasil pengujian secara parsial (Uji t) seperti yang disajikan pada Tabel 1 dapat diuraikan sebagai berikut:

1. Gaya Kepemimpinan

Variabel Gaya Kepemimpinan memiliki nilai signifikansi sebesar 0,048 . Nilai ini lebih kecil dari nilai Alpha yaitu $0,05(0,048<0,05)$ yang artinya bahwa variabel Gaya Kepemimpinan (X1) secara parsial berpengaruh terhadap Kinerja Karyawan (Y) sehingga dapat disimpulkan bahwa $\mathrm{H} 1$ diterima dan $\mathrm{H} 0$ ditolak, yang menyatakan bahwa Gaya Kepemimpinan secara parsial berpengaruh terhadap Kinerja Karyawan.

2. Budaya Organisasi

Variabel Budaya Organisasi memiliki nilai signifikansi sebesar 0,000 . Nilai ini lebih kecil dari nilai Alpha yaitu $0,05(0,000<0,05)$ yang artinya bahwa variabel Budaya Organisasi (X2) secara parsial berpengaruh terhadap Kinerja Karyawan (Y) sehingga dapat disimpulkan bahwa H2 diterima dan H0 ditolak, yang 
menyatakan bahwa Budaya Organisasi secara parsial berpengaruh terhadap Kinerja Karyawan.

\section{Uji Statistik F Secara Simultan (Uji F)}

Uji staitistik $F$ pada dasarnya menunjukkan adanya variabel independen atau bebas yang dimasukkan (Ghozali 2006). Cara menganalisis hasil uji statistik $t$ adalah sebagai berikut :

a. Jika $F$ hitung $\langle F$ tabel atau signifikan $F>$ 0,05 maka $\mathrm{H}_{0}$ diterima dan $\mathrm{H}_{\mathrm{a}}$ ditolak yang berarti tidak terdapat pengaruh yang signifikan antara variabel $\mathrm{X}$ secara bersama sama terhadap variabel $\mathrm{Y}$.

b. Jika $\mathrm{F}$ hitung $>\mathrm{F}$ tabel atau signifikan $\mathrm{F}<$ 0,05 , maka $\mathrm{H}_{0}$ ditolak dan $\mathrm{H}_{\mathrm{a}}$ diterima yang berarti terdapat pengaruh yang signifikan antara variabel $X$ secara bersama - sama terhadap variabel $\mathrm{Y}$.

Berdasarkan tabel 2, menunjukkan bahwa variabel Gaya Kepemimpinan (X1) dan Budaya Organisasi (X2) secara bersama-sama (simultan) berpengaruh terhadap variabel Kinerja Karyawan (Y). hal ini ditunjukkan dengan nilai signifikansi sebesar 0,000 dan lebih kecil dari nilai Alpha 0,05 $(0,000<0,05)$ sehingga dapat disimpulkan bahwa $\mathrm{H} 0$ ditolak dan H3 diterima, yang artinya Gaya Kepemimpinan dan Budaya Organisasi secara simultan (bersama-sama) berpengaruh terhadap Kinerja Karyawan.

Regresi linear berganda digunakan untuk mengukur kekuatan hubungan antara variabel atau lebih juga menunjukkan arah hubungan antara variabel dependen dengan variabel independen (Ghozali, 2006).

Koefisien determinasi $\left(\mathrm{R}^{2}\right)$ pada intinya mengukur seberapa jauh kemampuan sebuah model menerangkan variasi variabel dependen. Nilai koefisien determinasi adalah antara nol dan satu. Nilai $\mathrm{R}^{2}$ yang kecil berarti kemampuan variabel - variabel independen dalam menjelaskan variabel dependen sangat terbatas. Nilai yang mendekati satu berarti variabel variabel independen memberikan hampir semua informasi yang dibutuhkan untuk memprediksi variabel dependen Dan dalam penelitian ini nilai $\mathrm{R}^{2}$ yang dipakai adalah nilai Adjusted $\mathrm{R}^{2}$. Tidak seperti nilai $\mathrm{R}^{2}$, nilai Adjusted $\mathrm{R}^{2}$ dapat naik atau turun apabila satu variabel independen ditambahkan ke dalam model regresi dan berpengaruh secara signifikan terhadap variabel dependen (Ghozali, 2006).

Tabel 3 menunjukkan bahwa nilai Adjusted $R$ Square $\left(\mathrm{R}^{2}\right)$ sebesar 0,495. Artinya bahwa $49,5 \%$ variabel Kinerja Karyawan dapat dijelaskan oleh variabel Gaya Kepemimpinan dan Budaya
Organisasi, sedangkan 50,5\% variasi pada kinerja karyawan yang dapat dijelaskan oleh variabel lain diluar penelitian ini.

\section{Pengaruh Gaya Kepemimpinan (X1) Terhadap Kinerja Karyawan (Y)}

Berdasarkan hasil pengujian statistik t (Uji t), variabel Gaya Kepemimpinan memiliki nilai signifikansi sebesar 0,048 , nilai ini lebih kecil dari nilai Alpha yaitu $0,05(0,048<0,05)$ dan memiliki nilai $\mathrm{t}$ hitung sebesar 2,012, nilai ini lebih besar dari $\mathrm{t}$ tabel yaitu 1,997 (2,012 > 1,997) yang artinya variabel Gaya Kepemimpinan (X1) secara parsial berpengaruh terhadap Kinerja Karyawan (Y). Hal ini berarti bahwa Gaya Kepemimpinan memiliki pengaruh terhadap Kinerja Karyawan PT PLN (Persero) Area Manokwari.

Hasil analisis data menunjukkan bahwa gaya kepemimpinan yang diukur melalui Gaya Kepemimpinan Partisipatif memiliki pengaruh secara parsial terhadap Kinerja Karyawan. Dengan kata lain, hal ini menunjukkan bahwa karyawan pada PT PLN (Persero) Area Manokwari memiliki pemimpin yang mampu mempengaruhi para karyawannya di dalam perusahaan tersebut sehingga mau untuk melaksanakan pekerjaannya. Artinya bahwa, gaya kepemimpinan yang diterapkan di PT PLN (Persero) Area Manokwari sudah baik sehingga mampu untuk mempengaruhi kinerja karyawannya. Penerapan gaya kepemimpinan partisipatif di dalam PT PLN (Persero) Area Manokwari dapat dikatakan membawa hasil yang baik untuk setiap karyawan yang bekerja di dalamnya. Dan hal ini tentu saja akan berdampak baik terhadap pencapaian tujuan perusahaan karena pemimpin mampu mempengaruhi karyawannya dalam melaksanakan pekerjaannya untuk mencapai tujuan perusahaan.

Pengaruh yang diberikan pimpinan terhadap para karyawan memberikan kesempatan kepada karyawan untuk mampu berkoordinasi dengan pimpinan dan pegawai dalam hal tugas dan tanggung jawabnya. Selain koordinasi yang baik, para pimpinan di masing-masing unit mampu memberikan informasi kepada para anggota unit atau bawahannya. Secara umum berdasarkan wawancara dengan responden, setiap kegiatan yang melibatkan pegawai, para pimpinan bersedia mendengarkan masukan-masukan atau informasi dari bawahan. Hal inilah yang menjadikan para pegawai merasa termotivasi dalam bekerja. 
Tabel 1. Hasil Uji Statistik T (Uji t)

\begin{tabular}{|c|c|c|c|c|c|c|}
\hline & \multirow{2}{*}{ Model } & \multicolumn{2}{|c|}{ Unstandardized Coefficients } & \multirow{2}{*}{$\begin{array}{c}\begin{array}{c}\text { Standardized } \\
\text { Coefficients }\end{array} \\
\text { Beta }\end{array}$} & \multirow[t]{2}{*}{$\mathbf{T}$} & \multirow{2}{*}{ Sig. } \\
\hline & & B & Std. Error & & & \\
\hline & (Constant) & 23.805 & 3.094 & & 7.694 & .000 \\
\hline \multirow[t]{2}{*}{1} & TOTALGK & .111 & .055 & 208 & 2.012 & .048 \\
\hline & TOTALBO & .609 & .108 & .581 & 5.618 & .000 \\
\hline
\end{tabular}

a. Dependent Variable: TOTALKK

Sumber : Data Primer yang Diolah, 2018

Tabel 2. Hasil Uji Statistik F (Uji F)

ANOVA $^{a}$

\begin{tabular}{|c|c|c|c|c|c|c|}
\hline & Model & Sum of Squares & df & Mean Square & $\mathbf{F}$ & Sig. \\
\hline \multirow{3}{*}{1} & Regression & 894.371 & 2 & 447.186 & 33.370 & $.000^{b}$ \\
\hline & Residual & 857.659 & 64 & 13.401 & & \\
\hline & Total & 1752.030 & 66 & & & \\
\hline
\end{tabular}

a. Dependent Variable: TOTALKK

b. Predictors: (Constant), TOTALBO, TOTALGK

Sumber : Data Primer yang diolah, 2018.

Tabel 3. Hasil Uji Koefisien Determinasi $\left(\mathrm{R}^{2}\right)$

\begin{tabular}{|c|c|c|c|c|}
\hline \multicolumn{5}{|c|}{ Model Summary } \\
\hline Model & $\mathbf{R}$ & R Square & Adjusted R Square & Std. Error of the Estimate \\
\hline 1 & $.714^{\mathrm{a}}$ & .510 & .495 & 3.66073 \\
\hline
\end{tabular}

a. Predictors: (Constant), TOTALBO, TOTALGK

\section{Sumber : Data Primer yang diolah, 2018}

Hasil penelitian ini sejalan dengan penelitian yang dilakukan oleh Sasingkelo, dkk (2017) dan Rismawanti (2016), yang mana pada penelitian Sasingkelo, dkk (2017) menyatakan bahwa Gaya Kepemimpinan berpengaruh positif dan signifikan terhadap Kinerja Karyawan PT Horiguchi Sinar Insani di Kabupaten Minahasa Utara Provinsi Sulawesi Utara, dibuktikan dengan hasil pengujian yang diperoleh dari nilai t hitung adalah 3,148 > dari 2,007 nilai t tabel dan nilai signifikansi yang diperoleh adalah $0,003<$ dari 0,05 nilai Alpha. Sedangkan pada penelitian Rismawanti (2016) menyatakan bahwa Gaya Kepemimpinan berpengaruh signifikan terhadap Kinerja Karyawan PT Eka Daya Makassar, dibuktikan dengan hasil pengujian yang diperoleh dari nilai $\mathrm{t}$ hitung adalah 2,063 > dari 2,021 nilai t tabel dan nilai signifikansi yang diperoleh adalah $0,046<$ dari 0,05 nilai Alpha.

\section{Pengaruh Budaya Organisasi (X2) terhadap Kinerja Karyawan (Y)}

Berdasarkan hasil pengujian statistik $\mathrm{t}$ (Uji t), variabel Budaya Organisasi memiliki nilai signifikansi sebesar 0,000 , nilai ini lebih kecil dari nilai Alpha yaitu $0,05(0,000<0,05)$ dan nilai t hitung sebesar 5,618, nilai ini lebih besar dari nilai t tabel $(5,618>1,997)$, yang artinya variabel Budaya Organisasi (X2) secara parsial berpengaruh terhadap variabel Kinerja Karyawan (Y). Hal ini berarti bahwa Budaya Organisasi memiliki pengaruh terhadap Kinerja Karyawan PT PLN (Persero) Area Manokwari.

Hasil analisis data menunjukkan bahwa budaya organisasi yang diukur melalui indikator Profesionalisme, Jarak Manajemen, Percaya Pada Rekan Kerja dan Adaptasi memiliki pengaruh secara parsial terhadap Kinerja Karyawan. Dengan kata lain, hal ini menunjukkan bahwa karyawan PT PLN (Persero) Area Manokwari memiliki budaya organisasi yang baik di dalam perusahaan sehingga para karyawannya mampu bekerja dengan budaya organisasi yang ada di dalam perusahaan. Artinya bahwa, budaya organisasi PT PLN (Persero) Manokwari mampu menciptakan suatu kondisi kerja yang sesuai dan baik dengan para karyawan yang ada sehingga karyawan bisa merasa aman dan nyaman dalam bekerja dan hal ini berdampak pada kinerja 
karyawan sehingga kinerja karyawan menjadi baik.

Budaya organisasi yang ada di PT PLN (Persero) Area Manokwari sudah tertanam dalam setiap benak para karyawannya sehingga mampu menjadi pengaruh bagi kinerja karyawannya. Selain itu, budaya organisasi yang ada di PT PLN (Persero) Area Manokwari dapat dikatakan kuat karena dengan budaya yang ada mampu untuk menciptakan kondisi kerja yang kondusif untuk para karyawannya sehingga para karyawannya dapat melaksanakan pekerjaannya dengan baik. Sebab semakin baik budaya organisasi dalam suatu perusahaan, maka akan berdampak juga terhadap kinerja karyawan yang akan menjadi semakin baik pula. Budaya Organisasi di PT. PLN Persero) Area Manokwari pada dasarnya mendasarkan visi dan misi perusahaan yaitu mengpayakan agar tenaga listrik menjadi pendorong keggiatan ekonomi. Dengan melihat misi tersebut, perusahaan dituntut untuk bekerja dengan baik. Kerjasama antar pegawai dan pimpinan diupayakan berjalan sesuai dengan tujuan dan misi dari organisasi.

Budaya organisasi di obyek penelitian ini berdasarkan hasil penelitian menunjukkan hal yang pengaruh yang positif dengan kinerja. Para pegawai bekerja sesuai dengan Standar Operasional Prosedur (SOP) yang sudah ada dan di PT PLN (Area) Manokwari Papua Barat dinamika kerja pegawai adalah dalam suatu system. Artinya suatu departemen tidak bisa berjalan sendiri-sendiri tanpa memperhatikan departemen lain. Kerjasama antar departemen sebagai suatu kesatuan yang utuh inilah yang dijalankan oleh para pegawai sehingga kinerja para pegawai dapat meningkat. Sebagai langkah untuk pengawasan pada system kerja yang berjalan ini, pengamb ilan keputusan di sentralisasikan pada top managemen dalam hal ini kepala cabang.

Penelitian ini sejalan dengan penelitian yang dilakukan oleh Trang (2013) dan Antou (2013), yang mana penelitian dari Trang (2013) menyatakan bahwa Budaya Organisasi berpengaruh positif dan signifikan terhadap Kinerja Karyawan pada Perwakilan BPKP Provinsi Sulawesi Utara dibuktikan dengan hasil pengujian yang diperoleh dari nilai signifikansi sebesar $0,000<$ dari 0,05 nilai Alpha. Dan juga penelitian yang dilakukan oleh Antou (2013) yang menyatakan bahwa Budaya Organisasi berpengaruh positif terhadap Kinerja Pegawai pada Kantor Kelurahan Malalayang I Manado dibuktikan dengan hasil pengujian yang diperoleh dari nilai signifikansi sebesar 0,021 < dari 0,05 nilai Alpha.

\section{KESIMPULAN}

Berdasarkan hasil penelitian tentang pengaruh gaya kepemimpinan dan budaya organisasi terhadap kinerja karyawan PT PLN (Persero) Area Manokwari, maka dapat disimpulkan :

1. Terdapat pengaruh yang signifikan antara gaya kepemimpinan terhadap kinerja karyawan PT PLN (Persero) Area Manokwari. Gaya kepemimpinan partisipatif yang diterapkan pada PT PLN (Persero) Area Manokwari mampu untuk mempengaruhi karyawan PT PLN (Persero) Area Manokwari dalam melaksanakan setiap pekerjannya.

2. Terdapat pengaruh yang signifikan antara budaya organisasi terhadap kinerja karyawan PT PLN (Persero) Area Manokwari. Budaya organisasi yang ada pada PT PLN (Persero) Area Manokwari mampu menciptakan suatu kondisi kerja yang baik dan kondusif sehingga berdampak positif terhadap kinerja karyawannya.

3. Terdapat pengaruh yang signifikan antara gaya kepemimpinan dan budaya organisasi terhadap kinerja karyawan PT PLN (Persero) Area Manokwari. Hal ini menandakan bahwa gaya kepemimpinan dan budaya organisasi memiliki hubungan yang erat dengan kinerja karyawan. Karena semakin baik gaya kepemimpinan yang diterapkan, maka akan menciptakan suatu budaya organisasi yang baik pula. Dan hal ini tentu akan berdampak positif terhadap kinerja karyawan.

\section{DAFTAR PUSTAKA}

Antou, Doni Oktavianus. Gaya Kepemimpinan Dan Budaya Organisasi Pengaruhnya Terhadap Kinerja Pegawai Kantor Kelurahan Malalayang I Manado. ISSN $2302-1174$.

Bagia, I Wayan. (2015). Perilaku Organisasi. Graha Ilmu, Yogyakarta.

Bangun, Wilson. 2011. Intisari Manajemen. Edisi Kedua. PT Refika Aditama, Bandung.

Ghozali, Imam. (2006). Aplikasi Analisis Multivariate Dengan Program SPSS. Edisi Keempat. Semarang : Badan Penerbit Universitas Diponegoro.

Hariandja, E. T. Marihot. (2002). Manajemen Sumber Daya Manusia.Grasindo, Jakarta. 
Muchlas, Makmuri. (2005). Perilaku Organisasi. PT Raja Grafindo Persada, Jakarta.

Munandar, Ashar Suntoyo. (2008). Psikologi Industri Dan Organisasi. Universitas Indonesia, Jakarta.

Rifai, Imam dan Sadarusman. (2014). Analisis Pengaruh Budaya Organisasi Dan Gaya Kepemimpinan Terhadap Kinerja Pegawai Badan Pemberdayaan Masyarakat, Perempuan, Dan Keluarga Berencana Kabupaten Magelang. Telaah Bisnis. Volume 15, Nomor 2.

Rismawanti, Erni. (2016). Pengaruh Budaya Organisasi Dengan Gaya Kepemimpinan Terhadap Kinerja Karyawan Pada PT Eka Daya Kota Makassar. Jurnal SUPREMASI. Volume XI, Nomor 2.

Robbins, Stephen P. (1994). Teori Organisasi : Struktur, Desain Dan Aplikasi. Arcan, Jakarta.

Sasingkelo Reni, dkk. (2016). Pengaruh Gaya Kepemimpinan Dan Budaya Organisasi Terhadap Kinerja Karyawan Pada PT
Horiguchi Sinar Insani. Jurnal EMBA.

Vol 4, Nomor 4. Hal 2107 - 2114.

Sugiyono. 2016. Metode Penelitian Kuantitatif, Kualitatif, Dan R \& D. Alfabeta, Bandung.

Suprabowo, Budi Prasetyo. (2014). Pengaruh Gaya Kepemimpinan, Lingkungan Kerja Dan Kepuasan Kerja Terhadap Kinerja Karyawan Pada Divisi Properti PT Ramayana Lestari Sentosa, Tbk. Skripsi S-2. Universitas Esa Unggul Jakarta : Tidak Dipublikasikan.

Sobirin, Achmad. (2007). Budaya Organisasi : Pengertian, Makna Dan Aplikasinya Dalam Kehidupan Organisasi. Yogyakarta : Sekolah Tinggi Ilmu Manajemen TKPN.

Trang, Dewi Sandy. (2013). Gaya Kepemimpinan Dan Budaya Organisasi Pengaruhnya Terhadap Kinerja Karyawan (Studi Kasus Pada Perwakilan BPKP Provinsi Sulawesi Utara). Jurnal EMBA. Vol 1, Nomor 3. Hal $208-216$. 